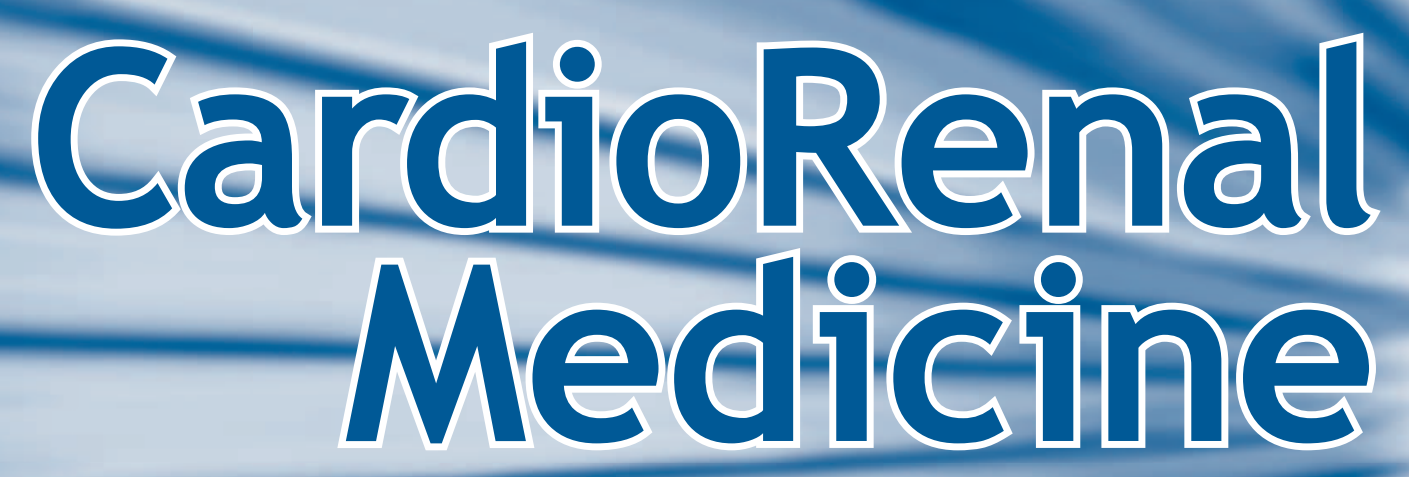




\section{Rediscover Vesalius}

The medical revolution of the 16th century brought to life for the 21st century

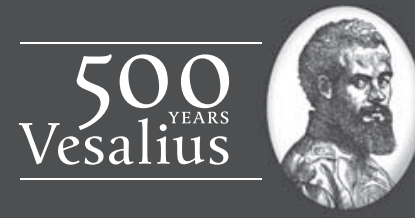

KARGER

Medical \& Scientific Publishers

\section{ANDREAS VESALIUS}

\section{The Fabric \\ of the Human Body}

\section{An Annotated Translation of the 1543 and 1555 Editions of}

\section{"De Humani Corporis Fabrica" by}

\section{DANIEL H. GARRISON \\ MALCOLM H. HAST}

with contributions by Vivian Nutton and Nancy Siraisi

For the first time ever, both editions of Andreas Vesalius' masterpiece "De Humani Corporis Fabrica" are accessible in the English language. They were critically compared and published in a modern layout transforming the Renaissance anatomical atlas for the 21st-century reader. More than 5,000 annotations cover anything from antique sources over Galenic references to the medical and cultural background of Vesalius' time. Also included are Vesalius' handwritten notes for a never published third edition.

To enable the reader and medical student to really study Vesalius' woodcut illustrations, the images were digitally enhanced and often enlarged to feature his painstaking work of marking each pertinent anatomical part with characters. All over Vesalius' descriptive text, the standard Latin Nomina Anatomica and Terminologia Anatomica provide the reader with the modern medical terminology.

Vesalius, A., The Fabric of the Human Body

An Annotated Translation of the 1543 and 1555 Editions of

"De Humani Corporis Fabrica Libri Septem" by

D.H. Garrison and M.H. Hast

CXX + 1338 p., 340 fig., in two volumes, hard cover, with slip case, 2014 $315 \times 435 \mathrm{~mm} / 12 \times 17^{\prime \prime}, 16 \mathrm{~kg} / 35 \mathrm{lbs}$

CHF 1,500.- / EUR 1,250.- / USD 1,650.00

ISBN 978-3-318-02246-9

\section{www.karger.com}

Postage and handling included

VAT \& import taxes excluded, no right to return

Prices subject to change, EUR price for Germany,

USD price for USA and Latin America only

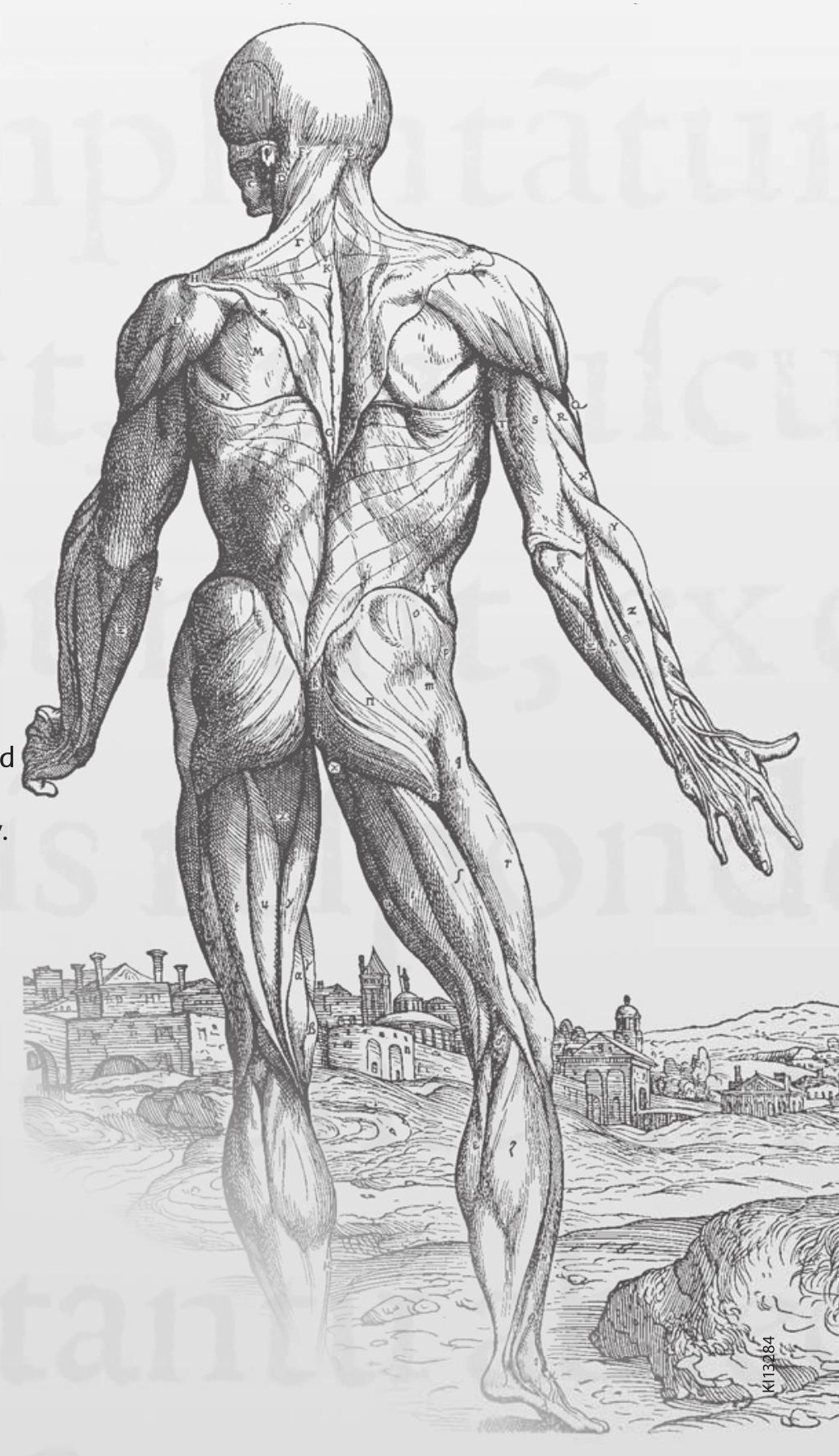




\section{CardioRenal Medicine}

Founded 2011 by J.R. Sowers

Editor

J.R. Sowers, Columbia, Mo.

\section{Assistant Editor}

B. Hunter, Columbia, Mo.

\section{Associate Editors}

S. Brietzke, Columbia, Mo.

M. Bursztyn, Jerusalem

K.C. Dellsperger, Augusta, Ga.

V. DeMarco, Columbia, Mo.

J.P. Dwyer, Nashville, Tenn.

K.C. Ferdinand, New Orleans, La.

J.M. Flack, Detroit, Mich.

E.P. Gomez-Sanchez, Jackson, Miss.
M.R. Hayden, Camdenton, Mo.

E.J. Henriksen, Tucson, Ariz.

J.M. Luther, Nashville, Tenn.

F. Murad, Washington, D.C.

C. Ronco, Vicenza

N. Stern, Tel Aviv

C.S. Stump, Tucson, Ariz.

A.T. Whaley-Connell, Columbia, Mo.

\section{Editorial Board}

M.A. Alpert, Columbia, Mo.

G.L. Bakris, Chicago, Ill.

M. Barbagallo, Palermo

S.B. Bender, Columbia, Mo.

T. Berl, Aurora, Colo.

S.L. Britton, Ann Arbor, Mich.

N.J. Brown, Nashville, Tenn.

V.M. Campese, Los Angeles, Calif.

A.R. Chacra, Sao Paulo

K. Chaudhary, Columbia, Mo.

M. Cooper, Melbourne, Vic.

C.F. Deacon, Copenhagen

P. Deedwania, Fresno, Calif.

L. Dominguez, Palermo

M. Epstein, Miami, Fla.

E. Fabbrini, St. Louis, Mo.
B. Falkner, Philadelphia, Pa.

E.D. Frohlich, New Orleans, La.

T. Fujita, Tokyo

J. Funder, Wandin East, Vic.

W.T. Garvey, Birmingham, Ala.

D. Goldsmith, London

C.E. Gomez-Sanchez, Jackson, Miss.

F. Giorgino, Bari

J.E. Hall, Jackson, Miss.

J.M. Hershman, Los Angeles, Calif.

M. Husain, Toronto, Ont.

S. Ito, Sendai

F. Jaisser, Paris

A. Jindal, Columbia, Mo.

K. Kalantar-Zadeh, Orange, Calif.

C.T. Kappagoda, Davis, Calif.

\section{KARGER}

Printed on acid-free and non-aging paper (ISO 9706) by

Stückle Druck, Ettenheim
Appears quarterly: 1 volume per year (4 issues) 


\section{CardioRenal Medicine}

S. Klein, St. Louis, Mo.

T. Klein, Biberach

Y. Kokubo, Osaka

D.T. Lackland, Charleston, S.C.

S.G. Lakoski, Colchester, Vt.

G. Lastra, Columbia, Mo.

P.S. Leung, Hong Kong

M. Levi, Aurora, Colo.

W. Lockette, Arlington, Va.

D.B. Lombard, Ann Arbor, Mich.

C. Manrique, Columbia, Mo.

L.A. Martinez-Lemus, Columbia, Mo.

R.W. McCallum, El Paso, Tex.

S.I. McFarlane, Brooklyn, N.Y.

B. Mitchell, Temple, Tex.

R. Muniyappa, Bethesda, Md.

P.M. Nilsson, Malmö

R. Nistala, Columbia, Mo.

D.K. Pandey, Chicago, Ill.

L. Peterson, St. Louis, Mo.

S. Petrides, Scottsdale, Ariz.

R.A. Phillips, Houston, Tex.

D. Porte, Jr., La Jolla, Calif.

W. Rainey, Ann Arbor, Mich.

M.K. Raizada, Gainesville, Fla.
A. Rathod, Los Angeles, Calif. R.S. Rector, Columbia, Mo.

J. Ren, Laramie, Wyo.

T. Rosenthal, Tel Aviv

L.M. Ruilope, Madrid

W.K. Samson, St. Louis, Mo.

R.W. Schrier, Aurora, Colo.

K.R. Short, Oklahoma City, Okla.

B. Singh, Paradise Valley, Ariz.

K. Sowers, Las Vegas, Nev.

H. Szerlip, Tucson, Ariz.

B. Terry, Columbia, Mo.

J. Thyfault, Columbia, Mo.

R.M. Touyz, Glasgow

E.M. Urbina, Cincinnati, Ohio

J. Varagic, Winston-Salem, N.C.

J.A. Vassalotti, New York, N.Y.

M. Velasco, Los Teques

K. Vijay, Scottsdale, Ariz.

D. Villarreal, Syracuse, N.Y.

R.C. Webb, Augusta, Ga.

R. Zimlichman, Tel Aviv

R.P. Zitsch III, Columbia, Mo.

M.-H. Zou, Oklahoma City, Okla.

\section{KARGER}

E-Mail karger@karger.com www.karger.com
() 2013 S. Karger AG, Basel

The Journal Home Page is available at: www.karger.com/crm 


\section{CardioRenal Medicine} Submission
CardioRenal Medicine only accepts online submissions
to:

http://mc.manuscriptcentral.com/crm

All further technical instructions can be found there.

\section{Conditions}

The journal will not publish articles which have been previously reported at any length or articles being considered for publication elsewhere. The authors must include a statement to this effect in their cover letter. If publication of the data in any form has occurred or is being contemplated, a copy of such publication should be in cluded with the submitted manuscript. Submission of an article for publication implies the transfer of the copyright from the author to the publisher upon acceptance. It is the author's responsibility to obtain permission to reproduce illustrations, tables, etc. from other publications. The manuscript should be written in English and the editors reserve the right to make appropriate corrections in grammar and style. Accepted papers become the permanent property of CardioRenal Medicine and may not be reproduced by any means, in whole or in part, without the written consent of the publisher. Information concerning financial disclosures (i.e. grants, funding, support, etc.) should be placed at the foot of the title page.

\section{Types of Articles for Acceptance}

1 Original Papers: Representing full sets of completed experiments in the areas of either clinical or basic research that answer a given question. Max. 3,000 words, incl. figures, tables. Maximum 25 references.

2 Reviews: Covering a timely topic by experts in the field. An Abstract is required and should be divided into Background, Summary and Key Messages. Max. 4,500 words, incl. figures, tables. Maximum 60 refer-

\section{Conflicts of Interest}

Authors are required to disclose any sponsorship or funding arrangements relating to their research and all authors should disclose any possible conflicts of interest. Conflict of interest statements will be published at the end of the article.

\section{Ethics}

Published research must comply with the guidelines for human studies and animal welfare regulations. Authors should state that subjects have given their informed consent and that the study protocol has been approved by the institute's committee on human research. Further, they should also state that animal experiments conform to institutional standards.

\section{Plagiarism Policy}

Whether intentional or not, plagiarism is a serious violation. We define a case of plagiarism if there is $25 \%$ similarity in the Results or Discussion that exactly reproduces another paper without citation.

If evidence of plagiarism is found before/after acceptance or after publication of the paper, the author will be offered a chance for rebuttal. If the arguments are not found to be satisfactory, the manuscript will be retracted and the author sanctioned from publishing papers for a period to be determined by the responsible Editor(s).

\section{Arrangement}

Title page: The first page of each paper should indicate the title, the authors' names, the institute where the work was conducted, a short title for use as running head, conflict of interest statement, and word count. Manuscripts are to be double-spaced and formatted using the same font, size 12 throughout text and references.

Full address: The exact postal address of the corresponding author complete with postal code must be given at the bottom of the title page. Please also supply phone and fax numbers, as well as e-mail address.

Key words: Please supply 3-10 key words in English that reflect the content of the paper.

Abstracts of Original Papers: Each paper needs an abstract of up to 250 words. Except for reviews, abstracts should be structured as follows:

Background/Aims: What is the major problem that

prompted the study?

Methods: $\quad$ How was the study performed?

Results: Most important findings?

Conclusion: Most important conclusion?

Abstracts of Reviews: Should be divided into the following subsections: Background, Summary and Key Messages. The Background should provide a brief clinical context for the review and is followed by the Summary, which should include a concise description of the main topics covered in the text. The Key Messages encapsulate the main conclusions of the review.

Footnotes: Avoid footnotes.

Tables and illustrations: Tables and illustrations (both numbered in Arabic numerals) should be prepared on separate pages. Tables require a heading and figures a legend, also prepared on a separate page. Electronically submitted b/w half-tone and color illustrations must have a final resolution of $300 \mathrm{dpi}$ after scaling, line drawings one of $800-1,200 \mathrm{dpi}$. Average table $=250$ words The maximum size of all uploaded files is $40 \mathrm{Mb}$.

\section{Color Illustrations}

Online edition: Color illustrations are reproduced free of charge. In the print version, the illustrations are reproduced in black and white. Please avoid referring to the colors in the text and figure legends.

Print edition: Up to 6 color illustrations per page can be integrated within the text at CHF 800.- per page.

\section{References}

In the text identify references by Arabic numerals [in square brackets]. Material submitted for publication but not yet accepted should be noted as [unpublished data] and not be included in the reference list. The list of references should include only those publications which are cited in the text. Do not alphabetize; number references in the order in which they are first mentioned in the text. The surnames of the authors followed by initials should be given. There should be no punctuation other than a comma to separate the authors. Preferably, cite all authors. Abbreviate journal names according to the Index Medicus system. (Also see International Committee of Medical Journal Editors: Uniform requirements for manuscripts submitted to biomedical journals. www. icmje.org).

Examples

(a) Papers published in periodicals: Chatel JM, Bernard $\mathrm{H}$, Orson $\mathrm{FM}$ : Isolation and characterization of two complete Ara h 2 isoforms cDNA. Int Arch Allergy Immunol 2003;131:14-18.

(b) Papers published only with DOI numbers:

Theoharides TC, Boucher W, Spear K: Serum interleukin-6 reflects disease severity and osteoporosis in mastocytosis patients. Int Arch Allergy Immunol DOI: $10.1159 / 000063858$

(c) Monographs: Matthews DE, Farewell VT: Using and Understanding Medical Statistics, ed 3, revised. Basel, Karger, 1996. (d) Edited books: DuBois RN: Cyclooxygenase-2 and colorectal cancer; in Dannenberg AJ, Dubois RN (eds) COX-2. Prog Exp Tum Res. Basel, Karger, 2003, vol 37, pp 124-137.

Reference Management Software: Use of EndNote is recommended for easy management and formatting of citations and reference lists.

\section{Digital Object Identifier (DOI)}

S. Karger Publishers supports DOIs as unique identifier for articles. A DOI number will be printed on the title page of each article. DOIs can be useful in the future for identifying and citing articles published online without volume or issue information. More information can be found at www.doi.org.

\section{Supplementary Material}

Supplementary material is restricted to additional data that are not necessary for the scientific integrity and conclusions of the paper. Please note that all supplementary files will undergo editorial review and should be submitted together with the original manuscript. The Editors reserve the right to limit the scope and length of the supplementary material. Supplementary material must meet production quality standards for Web publication without the need for any modification or editing. In general, supplementary files should not exceed $10 \mathrm{Mb}$ in size. All figures and tables should have titles and legends and all files should be supplied separately and named clearly. Acceptable files and formats are: Word or PDF files, Excel spreadsheets (only if the data cannot be converted properly to a PDF file), and video files (.mov, .avi, .mpeg).

\section{NIH-Funded Research}

The U.S. National Institutes of Health (NIH) mandates under the NIH Public Access Policy that final, peer-re viewed manuscripts appear in its digital database within 12 months of the official publication date. As a service to authors, Karger submits the final version of your article on your behalf to PubMed Central. For those selecting our premium Author's Choice ${ }^{\mathrm{TM}}$ service, we will send your article immediately upon publishing, accelerating the accessibility of your work without the usual embargo. More details on NIH's Public Access Policy is available at http://publicaccess.nih.gov/policy.htm

\section{Self-Archiving}

Karger permits authors to archive their pre-prints (i.e. pre-refereeing) or post-prints (i.e. final draft post-refereeing) on their personal or institution's servers, provided the following conditions are met: Articles may not be used for commercial purposes, must be linked to the publisher's version, and must acknowledge the publisher's copyright. Authors selecting Karger's Author's Choice ${ }^{\mathrm{TM}}$ feature, however, are also permitted to archive the final, published version of their article, which includes copyediting and design improvements as well as citation links.

\section{Page charges}

There are no page charges for papers of 5 printed pages. Each additional complete or partial page will be charged to the author at the rate of CHF 325.00 per page.

\section{Proofs}

Unless indicated otherwise, proofs are sent to the corresponding author and should be returned with the least possible delay. Alterations other than the correction of printer's errors are charged to the author.

\section{Reprints}

Order forms and a price list are sent with the proofs. Orders submitted after the issue is printed are subject to considerably higher prices.

\section{KARGER}

E-Mail karger@karger.com www.karger.com
(C) 2013 S. Karger AG, Basel 


\section{CardioRenal Medicine}

ISSN Print Edition: 1664-3828 ISSN Online Edition: 1664-5502

Journal Homepage: www.karger.com/crm

Publication Data: CardioRenal Medicine is published 4 times a year. Volume 3 with 4 issues appears in 2013.

Copyright: (c) 2013 S. Karger AG, Basel (Switzerland). All rights reserved. No part of this publication may be translated into other languages, reproduced or utilized in any form or by any means, electronic or mechanical, including photocopying, recording, microcopying, or by any information storage and retrieval system, without permission in writing from the publisher or, in the case of photocopying, direct payment of a specified fee to the Copyright Clearance Center.

Disclaimer: The statements, opinions and data contained in this publication are solely those of the individual authors and contributors and not of the publisher and the editor(s). The appearance of advertisements in the journal is not a warranty, endorsement, or approval of the products or services advertised or of their effectiveness, quality or safety. The publisher and the editor(s) disclaim responsibility for any injury to persons or property resulting from any ideas, methods, instructions or products referred to in the content or advertisements.
Subscription Rates: Subscriptions run for a full calendar year. Prices are given per year. Personal subscription:

Print or Online

CHF 260.-

EUR 210.CHF 308 .

USD 257.00

EUR 249.-

ostage and handling (added to print and print+online)

28.80 Europe, CHF 41.60 Overseas

EUR 22.40

USD 38.40

Free Online Subscription for Personal Subscribers Institutional subscription:

Print+Online combined

CHF 1472.-

CHF 1619.-

EUR 1187.-

EUR 1306.-

USD 1457.00

USD 1603.00

postage and handling (added to print and print+online)

CHF 36.- Europe, CHF 52.- Overseas

EUR 28.-

USD 48.00

Airmail surcharge: CHF 35.- / USD 33.00
Back Volumes and Single Issues: Information on availability and prices of single print issues and print or electronic back volumes can be obtained from Customer Service atservice@karger.ch.

Bibliographic Indices: This journal is regularly listed in bibliographic services.

Photocopying: This journal has been registered with the Copyright Clearance Center (CCC), as indicated by the code appearing on the first page of each article. For readers in the US, this code signals consent for copying of articles for personal or internal use, or for the personal or internal use of specific clients, provided that the stated fee is paid per copy directly to

Copyright Clearance Center Inc.

222 Rosewood Drive

Danvers, MA 01923 (USA)

A copy of the first page of the article must accompany payment. Consent does not extend to copying for general distribution, for promotion, for creating new works, or for resale. In these cases, specific written permission must be obtained from the copyright owner,

S. Karger AG, P.O. Box

CH-4009 Basel (Switzerland).

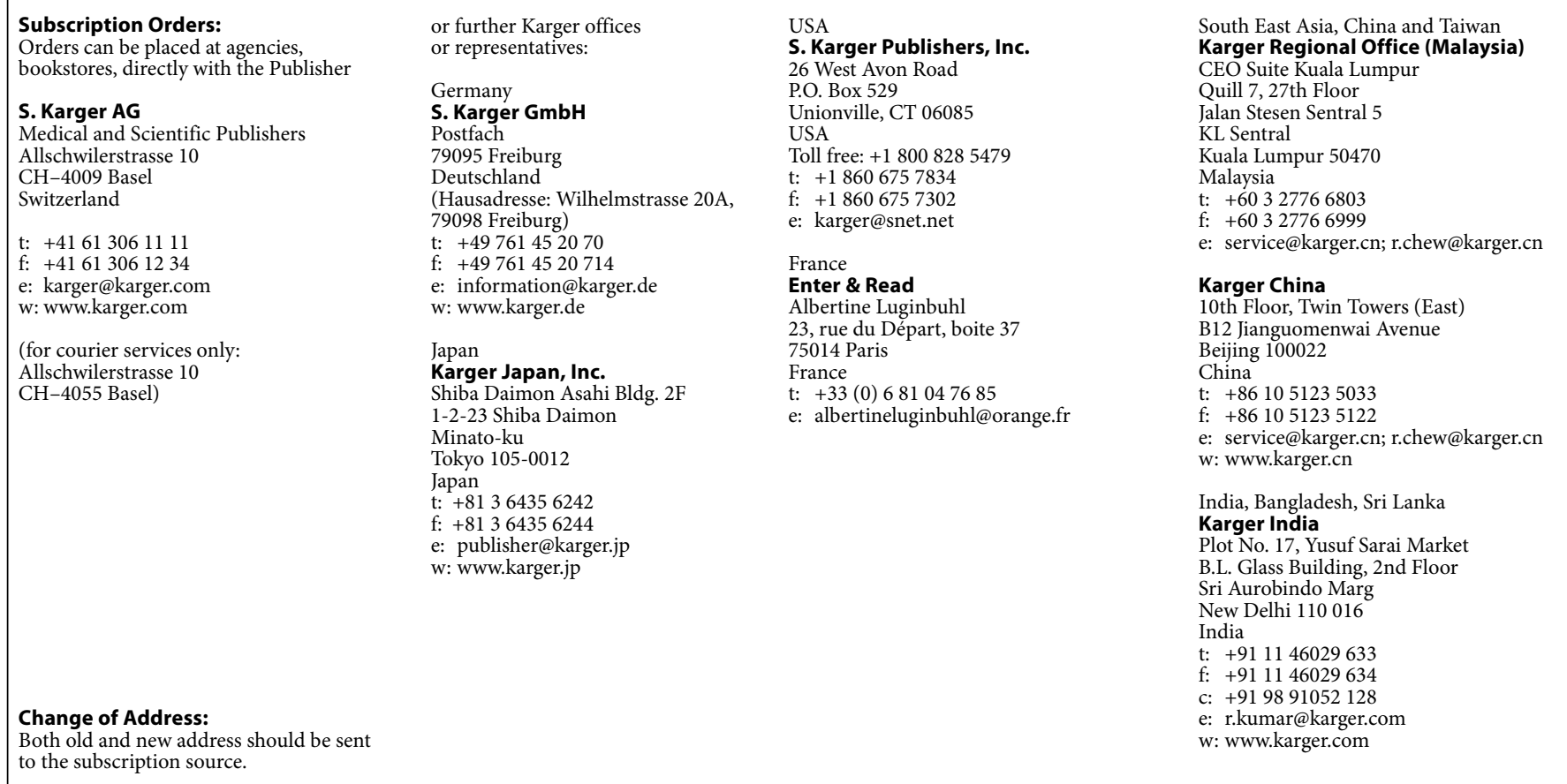

\section{KARGER}

E-Mail karger@karger.com www.karger.com
(C) 2013 S. Karger AG, Basel

The Guidelines for Authors are available at: www.karger.com/crm_Guidelines 


\section{Contents}

See the journal website for contents

KARGER Basel $\bullet$ Freiburg $\cdot$ Paris $\bullet$ London $\bullet$ New York $\cdot$ New Delhi $•$ Bangkok Beijing $\cdot$ Tokyo $\cdot$ Kuala Lumpur $\cdot$ Singapore $\bullet$ Sydney 


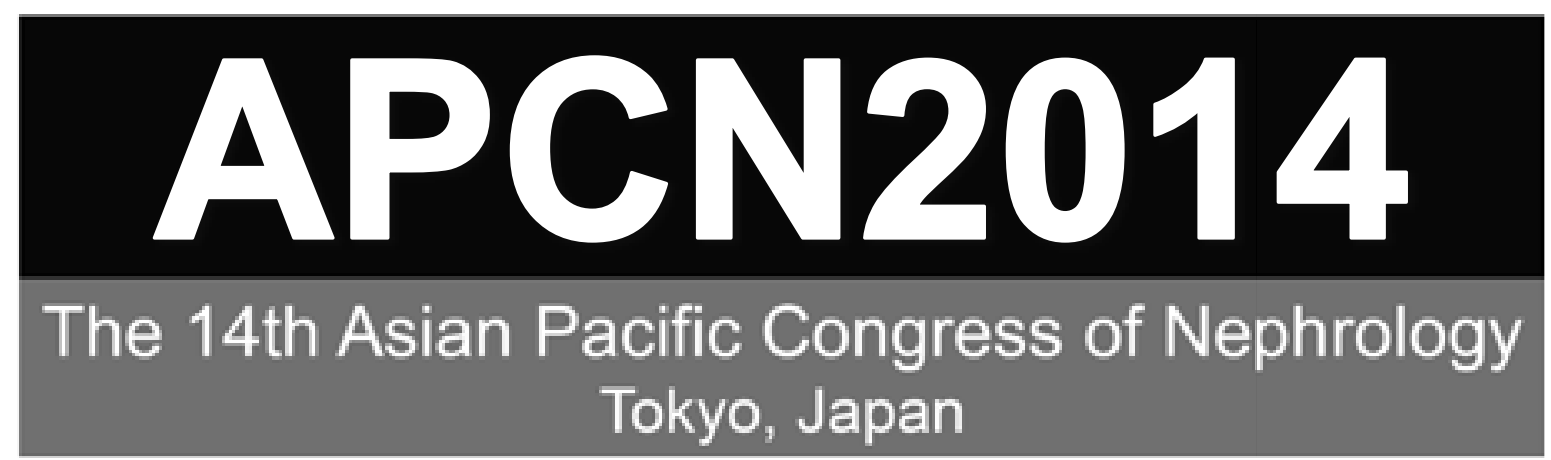

\section{Date : May 14 (Wed) - 17 (Sat), 2014 \\ Venue : Shinagawa Prince Hotel}

Congress President : Yasuhiko Tomino, MD, PhD

(Professor, Division of Nephrology, Department of Internal Medicine, Juntendo University Faculty of Medicine, Tokyo, Japan)

\begin{tabular}{|l|c|c|}
\multicolumn{1}{|c|}{ Registration fee } & \multicolumn{1}{c|}{$\begin{array}{c}\text { Early } \\
\text { (by Feb 28, 2014) }\end{array}$} & (after Mar 1, 2014) \\
\hline Doctors / Others & JPY 35,000 & JPY 45,000 \\
\hline $\begin{array}{l}\text { Student / Fellow / Trainee / Nurse / } \\
\text { Allied Health Care Staff }\end{array}$ & \multicolumn{2}{|c|}{ Free } \\
\hline Accompanying Person(s) & JPY 10,000 & JPY 10,000 \\
\hline
\end{tabular}

【Program main topics】

1. Diabetic kidney disease
2. IgA nephropathy
3. Nephrotic Syndrome and Podocyte Biology
4. Acute Kidney Injury $\quad \begin{aligned} & \text { 5. Hypertension } \\ & \text { 6. Renal replacement therapy } \\ & \text { 7. IgG4-related kidney disease } \\ & \text { 8. Renal regeneration }\end{aligned}$

《Period of Abstract Submission 》

September 10 (Tue) - December 10 (Tue), 2013

*Date and time should follow the Japanese Standard Time

Further conference information should be checked on the website!

\section{URL: http://www.mtoyou.jp/apen2014/ ـ}

\section{E-mail: apcn2014@mtoyou.jp}



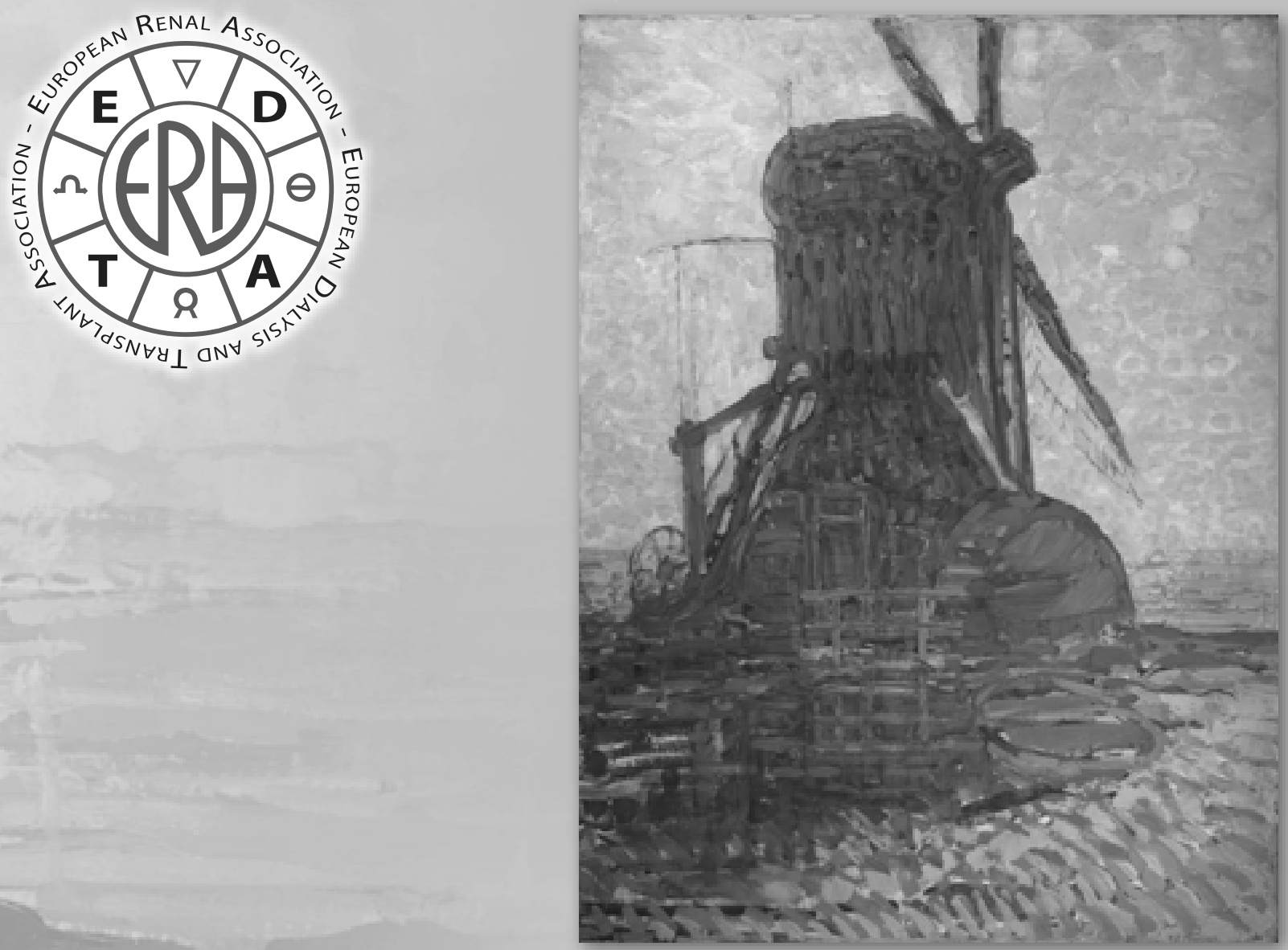

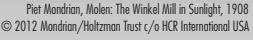

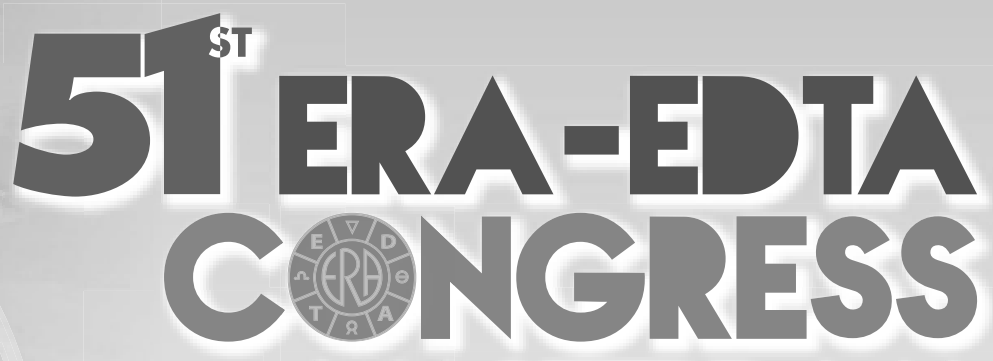
AMSTERDAM THE NETHERLANDS MAY3T' JUNE $3^{\circ}$ D)

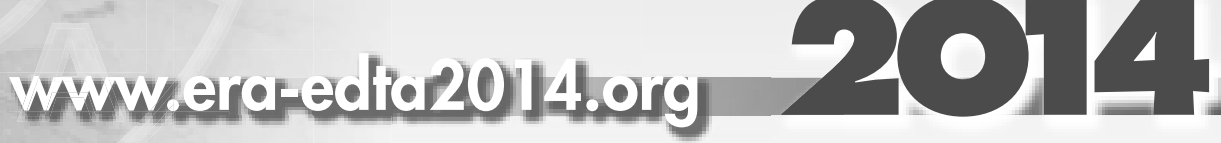




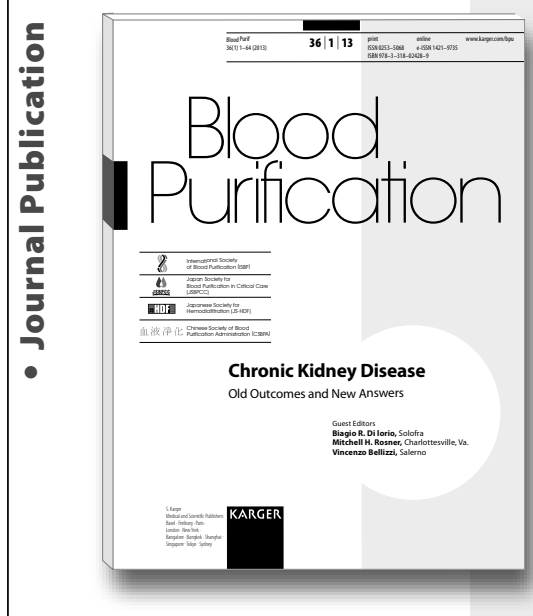

\title{
Chronic Kidney Disease
}

Old Outcomes and New Answers

\author{
Editors \\ B.R. Di lorio \\ M.H. Rosner \\ V. Bellizzi
}

Chronic Kidney Disease

Old Outcomes and New Answers

Editors: Di lorio, B.R. (Solofra); Rosner, M.H.

(Charlottesville, Va.); Bellizzi, V. (Salerno)

64 p., 10 fig., 10 tab., 2013

CHF 29.- / EUR 24.- / USD 34.00 (soft cover)

CHF 35.- / EUR 29.- / USD 41.00 (online)

Online version for institutional purchase

Prices subject to change

EUR price for Germany, USD price for USA only

ISBN 978-3-318-02428-9 (soft cover)

e-ISBN 978-3-318-02429-6

Special Topic Issue:

Blood Purification

Vol. 36, No. 1 (2013)

Included in subscription

Listed in MEDLINE/PubMed

Dear Librarian

I have reviewed this publication and

would like to recommend it for our library.

Recommended by:

Department:

\section{Contents}

Editorial

- Chronic Kidney Disease: Old Outcomes and New Answers: Rosner, M.H.

- Genomics and Proteomics: How Long Do We Need to Reach

Clinical Results? Matafora, V.; Bachi, A.; Capasso, G.

- Paricalcitol and Cardiorenal Outcome: From the IMPACT Study

to Clinical Practice: Bellasi, A.; Galassi, A.; Salvi, P.; Cozzolino, M.

- Coronary Artery Calcification and Outcomes in

Diabetic Patients with and without Chronic Kidney Disease:

Russo, D.; Morrone, L.F.P.; Imbriaco, M.; Pota, A.; Russo, L.;

Scognamiglio, B.; Sorrentino, R.

- Does It Make Sense to Measure Only the Brachial Blood

Pressure? Salvi, P.; Bellasi, A.; Di lorio, B.

- Subendocardial Viability Ratio Predicts Cardiovascular Mortality

in Chronic Kidney Disease Patients: Di Micco, L.; Salvi, P.; Bellasi, A.; Sirico, M.L.; Di lorio, B.

- Higher Doses of Erythropoietin-Stimulating Agents and

Hyporesponsiveness to Their Effects Are Associated with Increased Mortality among Prevalent Hemodialysis Patients: Nishio, A.; Chhatkuli, B.P.; Ma, J.Z.; Kalantari, K.

- Therapy of Anemia: Is It Only a Number to Reach or Are There

Other Variables to Control? Del Vecchio, L.; Locatelli, F.

- Low-Protein Diet or Nutritional Therapy in Chronic Kidney

Disease? Bellizzi, $\mathbf{v}$.

- Personal Daily Dialysis: The Evolution of the Artificial Kidney:

Kim, J.C.; Ronco, C.

-FGF23: A Mature Renal and Cardiovascular Risk Factor?

Zoccali, C.; Yilmaz, M.I.; Mallamaci, F.

- Blood Pressure Variability in Chronic Kidney Disease Patients: Mallamaci, F.; Tripepi, G. 


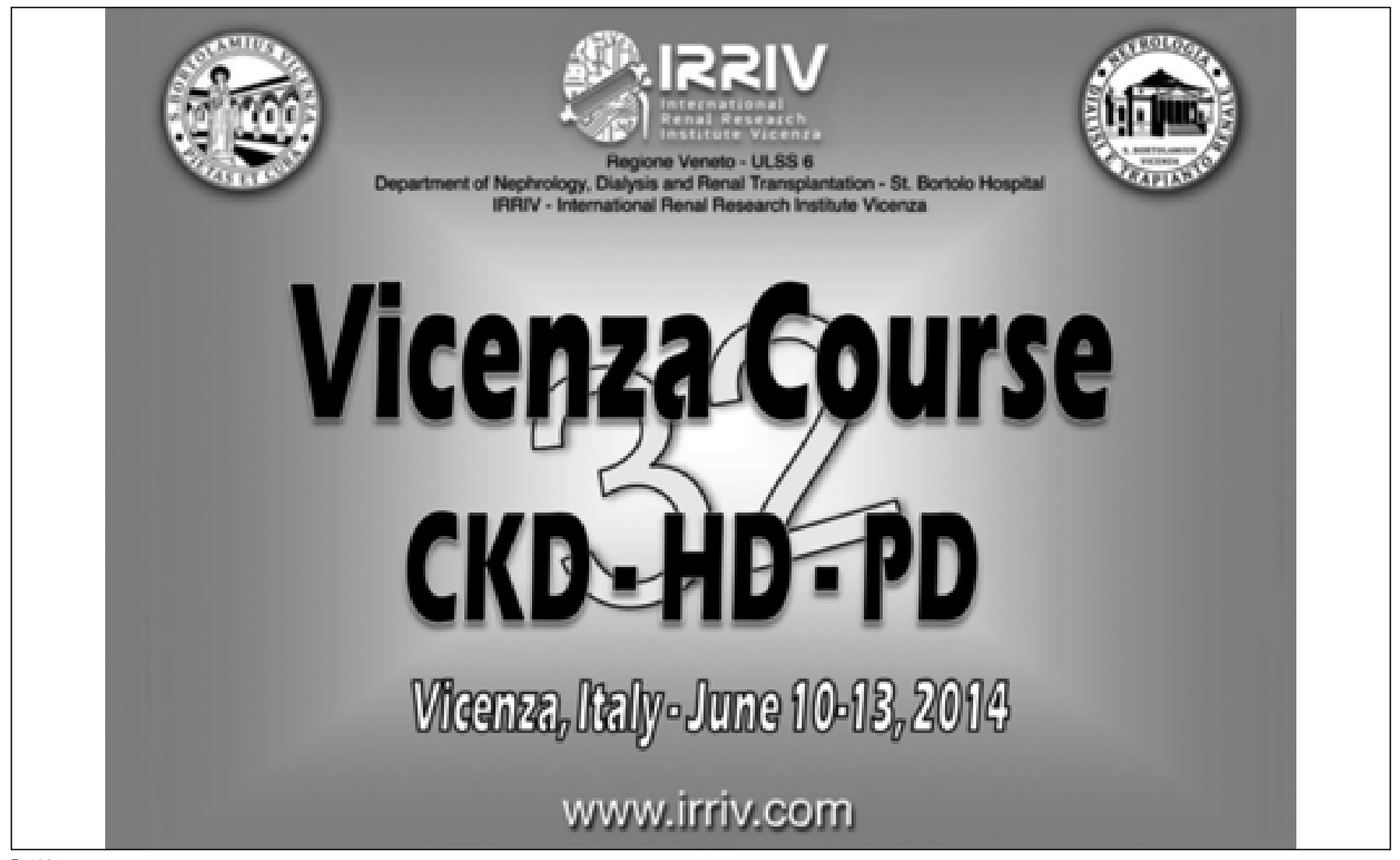

F14221

\begin{tabular}{|c|c|c|c|c|}
\hline $\begin{array}{l}\text { Series Editor } \\
\text { Borer, J.S. } \\
\text { (New York, N.Y.) }\end{array}$ & \multicolumn{3}{|c|}{$\begin{array}{l}\text { Well-documented scientific studies to aid progress in the management of cardiac } \\
\text { disease } \\
\text { This series is devoted to current problems in clinical and preventive cardiology. Edited or } \\
\text { authored by renowned specialists, volumes in this series are designed to provide up-to-date } \\
\text { and comprehensive coverage of a particular subject. Some volumes record the proceedings } \\
\text { of important symposia. Special emphasis is given to new findings relating to diagnostic } \\
\text { and therapeutic measures, cardiac pharmacology, and drug-disease interactions, and to the } \\
\text { fundamental cellular and molecular pathophysiology underlying cardiovascular disease pro- } \\
\text { cesses. Areas of interest range throughout the field of cardiology to include coronary artery } \\
\text { disease, congenital and acquired valvular and other structural heart diseases, primary myo- } \\
\text { cardial diseases and primary and secondary electrophysiological dysfunction. }\end{array}$} & 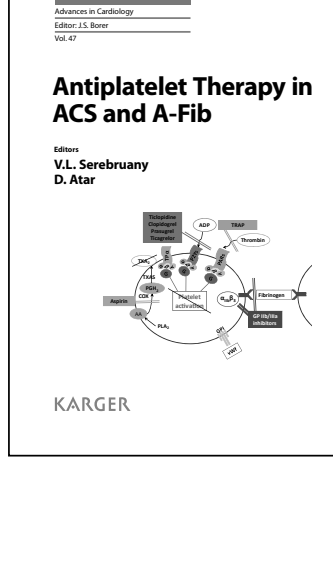 \\
\hline $\begin{array}{l}\text { Advances in Cardiology } \\
\text { ISSN } 0065-2326\end{array}$ & \multirow{2}{*}{$\begin{array}{l}\text { Vol. 47: Antiplatelet Therapy in } \\
\text { ACS and A-Fib } \\
\text { Editors: Serebruany, V.L. } \\
\text { (Towson, Md.); Atar, D. (Oslo) } \\
\mathrm{VI}+170 \text { p., } 20 \text { fig., } 6 \text { in color, } \\
16 \text { tab., hard cover, } 2012 \\
\text { CHF 142.- / EUR 118.- / USD } 167.00 \\
\text { ISBN 978-3-318-02168-4 } \\
\text { e-ISBN 978-3-318-02169-1 }\end{array}$} & $\begin{array}{l}\text { Vol. 46: Obstructive Sleep } \\
\text { Apnea in Adults - Relationship } \\
\text { with Cardiovascular and } \\
\text { Metabolic Disorders }\end{array}$ & \multirow{2}{*}{$\begin{array}{l}\text { Vol. 45: Cardiovascular } \\
\text { Diabetology: Clinical, } \\
\text { Metabolic and Inflammatory } \\
\text { Facets } \\
\text { Editors: Fisman, E.Z. (Holon); } \\
\text { Tenenbaum, A. (Tel-Hashomer) } \\
\text { XIV + } 174 \text { p., } 23 \text { fig., } 5 \text { tab., hard cover, } \\
2008 \\
\text { CHF 180.- / EUR 150.- / USD } 212.00 \\
\text { ISBN 978-3-8055-8427-2 } \\
\text { e-ISBN 978-3-8055-8428-9 }\end{array}$} & \multirow{2}{*}{$\begin{array}{l}\text { Vol. 44: Atherosclerosis, } \\
\text { Large Arteries and } \\
\text { Cardiovascular Risk } \\
\text { Editors: Safar, M.E. (Paris); } \\
\text { Frohlich, E.D. (New Orleans, La.) } \\
\text { VIII + } 360 \text { p., } 63 \text { fig., } 1 \text { in color, } 29 \text { tab., } \\
\text { hard cover, } 2007 \\
\text { CHF 216.- / EUR 180.- / USD } 254.00 \\
\text { ISBN 978-3-8055-8176-9 } \\
\text { e-ISBN 978-3-318-01395-5 }\end{array}$} \\
\hline $\begin{array}{l}\text { Listed in bibliographic services } \\
\text { including Current Contents }{ }^{\circledR} \text {, Index } \\
\text { Medicus/MEDLINE, Biological } \\
\text { Abstracts. }\end{array}$ & & $\begin{array}{l}\text { Author: Lurie, A. (Paris) } \\
\text { XVI + } 272 \text { p., } 95 \text { fig. in color, } \\
37 \text { tab., hard cover, 2011 } \\
\text { CHF 167.- / EUR 139.- / USD } 196.00 \\
\text { ISBN 978-3-8055-9645-9 } \\
\text { e-ISBN 978-3-8055-9646-6 }\end{array}$ & & \\
\hline $\begin{array}{l}\text { Read it online: } \\
\text { www.karger.com/adcar }\end{array}$ & \multicolumn{3}{|c|}{$\begin{array}{l}\text { Prices subject to change } \\
\text { EUR price for Germany, USD price for USA only }\end{array}$} & \\
\hline
\end{tabular}




\section{Metabolic abnormalities, heart and kidney disease}

\section{CardioRenal Medicine}

\begin{tabular}{l} 
Editor \\
\hline J.R. Sowers, Columbia, Mo. \\
Assistant Editor \\
\hline B. Hunter, Columbia, Mo. \\
Associate Editors \\
S. Brietzke, Columbia, Mo. \\
M. Bursztyn, Jerusalem \\
K.C. Dellsperger, Columbia, Mo. \\
V. DeMarco, Columbia, Mo. \\
J.P. Dwyer, Nashville, Tenn. \\
K.C. Ferdinand, New Orleans, La. \\
J.M. Flack, Detroit, Mich. \\
E.P. Gomez-Sanchez, Jackson, Miss.
\end{tabular}

M.R. Hayden, Camdentown, Mo. E.J. Henriksen, Tucson, Ariz. J.M. Luther, Nashville, Tenn. F. Murad, Washington, D.C.

C. Ronco, Vicenza

N. Stern, Tel Aviv C.S. Stump, Tucson, Ariz.

A.T. Whaley-Connell, Columbia, Mo.
Affiliated with

Cardio Renal Society of America

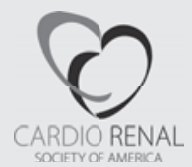

\section{CardioRenal Medicine}

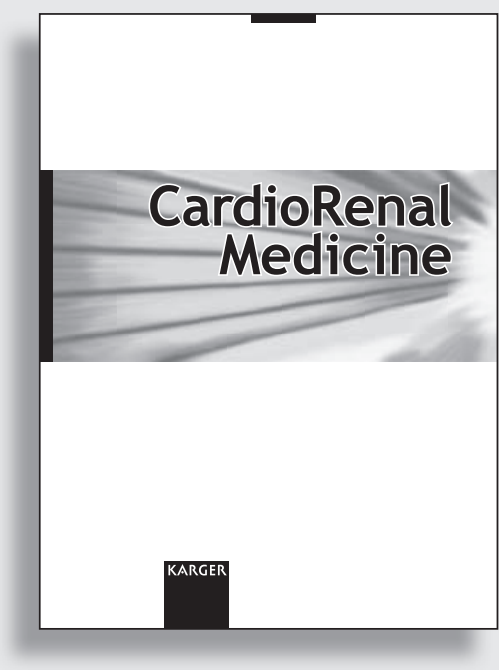

More information at

\section{www.karger.com/crm}

- Pay-per-View and Subscriber Access to Full Text

- Full Table of Contents

- Full Editorial Board

- Free Abstracts and Selected Articles

- Online Sample Issue

- Submission/Guidelines for Authors

- Subscription Details

- Free Alert Service

- Online Library Recommendation

\section{Selected contributions}

- Preclinical Cardiorenal Interrelationships in Essential Hypertension:

Tsioufis, C.; Tsiachris, D.; Kasiakogias, A.; Dimitriadis, K.; Petras, D. (Athens);

Goumenos, D. (Patras); Siamopoulos, K. (loannina); Stefanadis, C. (Athens)

- A Comparison of Traditional and Novel Definitions (RIFLE, AKIN, and KDIGO) of Acute Kidney Injury for the Prediction of Outcomes in Acute Decompensated Heart Failure: Roy, A.K.; Mc Gorrian, C.; Treacy, C.; Kavanaugh, E.; Brennan, A.; Mahon, N.G.; Murray, P.T. (Dublin)

- Ultrasonography: Ariadne's Thread in the Diagnosis of the Cardiorenal Syndrome: Di Lullo, L. (Tivoli); Floccari, F. (Civitavecchia); Granata, A. (Catania); D'Amelio, A. (Lecce); Rivera, R. (Monza); Fiorini, F. (Rovigo); Malaguti, M. (Civitavecchia); Timio, M. (Foligno)

- Cardiorenal Syndrome Type 1 May Be Immunologically Mediated: A Pilot Evaluation of Monocyte Apoptosis: Virzì, G.M.; Torregrossa, R.; Cruz, D.N.; Chionh, C.Y.; de Cal, M.; Soni, S.S. (Vicenza); Dominici, M. (Modena); Vescovo, G. (Vicenza); Rosner, M.H. (Charlottesville, Va.); Ronco, C. (Vicenza)

- Myocardial Stunning with Hemodialysis: Clinical Challenges of the Cardiorenal Patient: Zuidema, M.Y.; Dellsperger, K.C. (Columbia, Mo.)

- Systolic Heart Function, Kidney Filtration and the Number of Coronary Atherosclerotic Plaques in Lean and Overweight Patients: Ferreira-Filho, S.R.; Rosa, C.A.S.; Reis, S.S.A.; Botelho, R.V.; Pereira, V.J.; Pellaza, B.B. (Uberlândia)

- Relationship between Changes in Plasma Adiponectin Concentration and Insulin Sensitivity after Niacin Therapy: Fraterrigo, G. (St. Louis, Mo./Rome); Fabbrini, E.; Mittendorfer, B. (St. Louis, Mo.); 0'Rahilly, S. (Cambridge); Scherer, P.E. (Dallas, Tex.); Patterson, B.W.; Klein, S. (St. Louis, Mo.)

- Phosphoprotein Phosphatase PP2A Regulation of Insulin Receptor Substrate 1 and Insulin Metabolic Signaling: Mandavia, C.; Sowers, J.R. (Columbia, Mo.)
The journal CardioRenal Medicine explores the mechanisms by which obesity and other metabolic abnormalities promote the pathogenesis and progression of heart and kidney disease (cardiorenal metabolic syndrome). It provides an interdisciplinary platform for the advancement of research and clinical practice, focussing on translational issues.

Attention is paid to the fact that some metabolic abnormalities cluster with heart and chronic kidney disease, and collectively this is called the cardiorenal metabolic syndrome. Moreover, certain metabolic abnormalities of the heart promote impaired coronary artery endothelial function, diastolic dysfunction and ischemic reconditioning that parallel glomerular hyperfiltration and impairments in proximal tubule handling of sodium and albumin. Another point of focus is the role of the obesity epidemic in promoting the increasing incidence of heart and kidney disease in industrialized countries and the prevailing problems of insufficient exercise and excessive consumption of cheap, unwholesome food in promotion of the cardiorenal metabolic syndrome in both adults and children.

CardioRenal Medicine addresses a multidisciplinary audience consisting of nephrologists, cardiologists, nutritionists, endocrinologists, physiologists and general internists.

2014: Vol. 4

4 issues per volume

Language: English

ISSN: 1664-3828 (print)

e-ISSN: 1664-5502 (online) 


\section{CardioRenal Medicine}

\section{Original Papers}

221 Changes in Central Aortic Pressure, Endothelial Function and Biomarkers in Hypertensive African-Americans with the Cardiometabolic Syndrome: Comparison of Amlodipine/Olmesartan versus Hydrochlorothiazide/ Losartan

Khan, B.V.; Merchant, N.; Rahman, S.T.; Ahmad, M.;

Parrott, J.M.; Umar, K.; Johnson, J.; Ferdinand, K.C. (Atlanta, Ga.)

232 What Is Hypercalcemia? The Importance of Fasting Samples

Siyam, F.F.; Klachko, D.M. (Columbia, Mo.)

239 Clinical and Echocardiographic Predictors of Cardiorenal Syndrome Type I in Patients with Acute Ischemic Right Ventricular Dysfunction Tandon, R.; Mohan, B.; Chhabra, S.T.; Aslam, N.; Wander, G.S. (Ludhiana)

246 Serum Uric Acid Is Not an Independent Risk Factor for Premature Coronary Artery Disease

Zand, S.; Shafiee, A.; Boroumand, M.; Jalali, A.; Nozari, Y. (Tehran)
254 Impaired Leukocytes Autophagy in Chronic Kidney Disease Patients

Chen, W.-T.; Hung, K.-C.; Wen, M.-S.; Hsu, P.-Y.; Chen, T.-H. (Taoyuan); Wang, H.-D. (Hsinchu); Fang, J.-T.; Shie, S.-S.; Wang, C.-Y. (Taoyuan)

265 Cardiorenal Metabolic Syndrome and Diabetic Cognopathy

Hayden, M.R. (Columbia, Mo.); Banks, W.A. (Seattle, Wash.); Shah, G.N. (St. Louis, Mo.); Gu, Z.; Sowers, J.R. (Columbia, Mo.)

264 Erratum

283 Acknowledgement to the Reviewers after 284 Contents Vol. 3, 2013 